for the year 1962, the Director states that the function of the panel is purely advisory and it helps to extend greatly the body of specialist knowledge on which the Museum can call. The Director also directs attention to the recruitment of senior officers in museums as a matter which is giving increasing cause for concern. Such posts can bo vory rewarding to academic individuals especially if they are interested in certain techniques for spreading knowledge and have an original turn of mind. Unfortunately, universities appear to produce fewer and fewer suitable candidates and, for example, it is rare to find an honours graduate in zoology prepared to undertake research in taxonomy. It is pointed out that the Museum has been deprived of the full use of the north-east and north-west wings ever since their structural shortcomings were detected almost twenty years ago. At tho best, it will be another three years before they can be reconstructed and equipped.

\section{The Western Australian Museum, Perth}

IN 1960, the Art Gallery of the Western Australian Museum, Perth, was separated from the Museum premises and a programme of building alterations was immediately commeneed (Annual Reports, 1960-61 (pp. 40), and 1961-62 (pp. 43). Perth: Western Australian Museum, 1962). As a result, the staff has at its disposal modern and well-equipped accommodation, a satisfactory library, and good storage facilities for a large part of the collections. As a natural sequence to these improvements, plans were made for the modernization of the exhibition galleries, and these included a rapid-change display case. The report for $1960-61$ gives details and plans of this ingenious showcase. In 1961-62 the most important development in the educational services provided by the Museum was the creation of a new Children's Centre. Here specimens could be handled and the pattern followed which is now accepted in many museums schools services. The field work organized by the Museum was extensive and linked both with the Museum collections and the individual research work of members of the staff.

\section{Pugwash Conference in Yugoslavia}

Some sixty scientists from two dozen countries will meet in Dubrovnik (Yugoslavia) on September 20 to discuss the crucial problem of how to achieve world-wide disarmament and security. Their meeting, which continues until September 25, is the eleventh in the series of Pugwash Conferences (Conferences on Science and World Affairs) and follows the two held in Cambridge and London in the autumn of last year. The title of the Conference is "Current Problems of Disarmament and World Security", and it will lay particular stress on the part that non-aligned nations can play in disarmament and the possibility of setting up nuclear-free zones in Europe and elsewhere. The main topies to be discussed are: the abolition of delivery systems, inspection and control in the first stage of disarmament, the spread of nuclear weapons, nuclear-free zones, the role of nonaligned nations, and the test ban and problems of detection.

Among the participants will be a dozen scientists from the United States, a dozen from the U.S.S.R. and six from the United Kingdom. Among those coming from the United States are Profs. Paul Doty, Franklin Long and I. I. Rabi; from the U.S.S.R., Academicians V. A. Kirillin, I. E. Tamm and A. N. Tupolev; and from the United Kingdom, Sir John Cockcroft and Prof. P. M. S. Blackett. As with previous Pugwash Conferences, where maximum freedom of discussion is all-important, the Conference will be private. But also, as usual, the findings of the scientists will be sent to Heads of States and other interested bodies. The host for the Conference will be the Council of Yugoslav Academies. Further information can be obtained as follows: until September 13, Prof. J.
Rotblat, secretary-general of the Pugwash Continuing Committee, St. Bartholomew's Hospital Medical College, London, E.C.1; from September 13 until 18, Gerald Leach, 110 Regent's Park Road, London, N.W.1.

\section{Announcements}

The Minister of Power and the Secretary of State for Scotland have appointed Prof. A. L. L. Baker, professor of concrete structures and technology in the Imperial College of Science and Technology, London, and Mr. R. K. Christy, H.M. Chief Inspector of Factories, to be members of their Nuclear Safety Advisory Committee.

MR. G. B. Townsend has been appointed technical manager of the Professional Television Department of the Rank Cintel Division of the Rank Organization. Mr. Townsend was formerly with the General Electric Company, having joined its Research Laboratories at Wembley in 1940 , where he worked on radar and secret weapons and was afterwards responsible for the research work on television problems. In 1961 he transferred to G.E.C. (Electronics), Ltd., as manager of the new Television Equipment Department. Mr. Townsend is president of the British Amateur Television Club and chairman of the Council of the Television Society.

A MEETrNa of the Biochemical Society will be held in Aberdeen during September 26-27. A colloquium on "The Metabolism of Protozoa" will be held during the moeting. Further information can be obtained from the Meetings Secretary, the Biochemical Society, 20 Park Crescent, London, W.1.

A conference on "The Design and Use of Microwave Valves", arranged by the Electronics Division of the Institute of Electrical Engineers, will be held at the Institute during October 16-18. Further information can be obtained from the Secretary, Institution of Electrical Engineers, Savoy Place, London, W.C.2.

The twonty-fourth national Conference for the Preservation of the Countryside, arranged by the Council for the Preservation of Rural England, will be held in Plymouth during October 10-12. Further information can be obtained from the Secretary, Council for the Preservation of Rural England, 4 Hobart Place, London, S.W.1.

The seventh conference on "Analytical Chemistry in Nuclear Technology", sponsored by the Analytical Chrmistry Division of the Oak Ridge National Laboratory, will be held in Gatlinburgh, Tennessee, during October 8-10. Further information can be obtained from C. D. Susano, Oak Ridge National Laboratory, P.O. Box X, Oak Ridge, Tennessee.

AN ordinary meeting of the North of England Section of the Society for Analytical Chemistry will be held in Manchester on September 28. A paper on "The Chemistry of Wines and Spirits" will be presented and discussed at the meeting. Further information can be obtained from the Society for Analytical Chemistry, 14 Belgrave Square, London, S.W.1.

THE Basic Science Section of the British Ceramic Society is holding a meeting on "Point Defects in NonMetallic Solids" at Leamington Spa during October 14-16. Registration is necessary, and further information can be obtained from Dr. J. P. Roberts (honorary section secretary), Houldsworth School of Applied Science, the University, Leeds, 2.

THE fourth International Aerosol Congress and Exhibition, organized by the British Aerosol Manufacturers' Association at the invitation of the Federation of European Aerosol Associations, will be held in Brighton during October 7-12. Further information can be obtained from the Conference Secretary, International Aerosol Congress Office, Milbanke Way, Bracknell, Berks. 